\title{
1316
}

UCR L- 51742

\section{REDUCED, A DATA REDUCTION CODE}

Neil Maron

March 15, 1975

\section{MASTER}

Prepared for U.S. Energy Research \& Development

Administration under contract No. W-7405-Eng-48

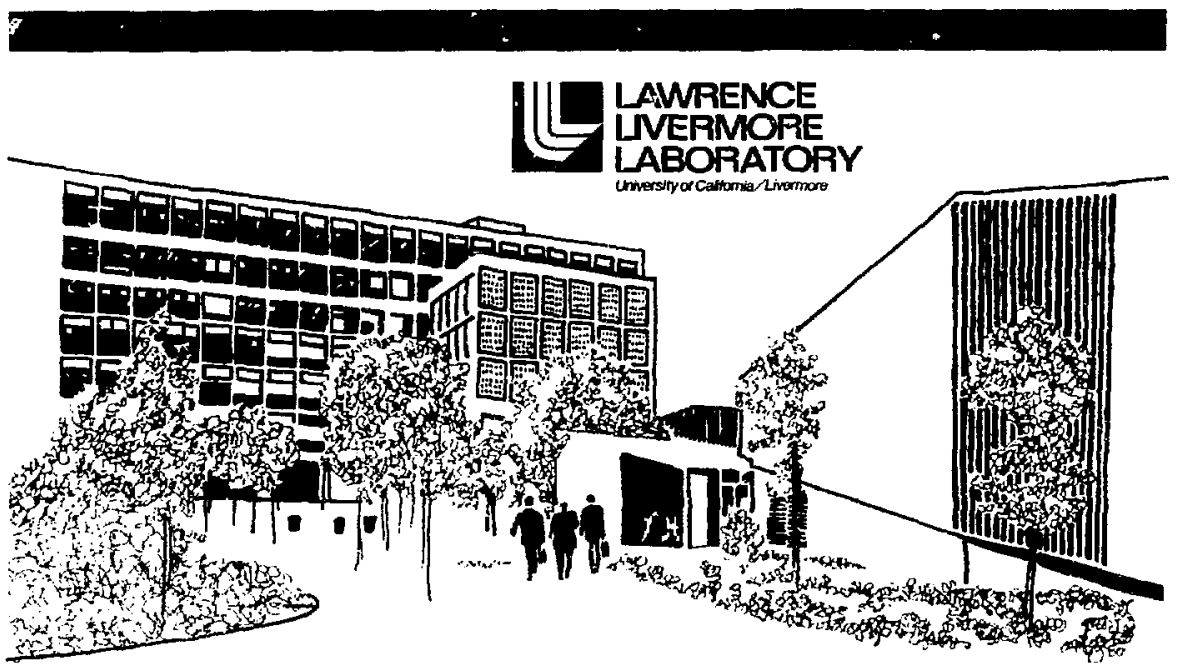


NOTICE

"This report was prepared as an account of work sponsored by the United States Government. Neither the United States nor the United States Energy Resenrch \& Development Administration, nor any of their zmplayees, nor sny of their contractors, subcontractors, of their employees, makes any warranty, express or implied, or assumes any legal liability "or responsibility" for the accuracy, completeness or usefulness of any information, apparatus, product or process disclosed, or represents that its use would not infringe privately-owned rights."

Printed in the United States of America Available from

National Technical Information Service U.S. Department of Commerce 5285 Port Royal Road Springfield, Virginia 22151

Price: Printed Copy $\$$ 贲; Microfiche $\$ 2.25$

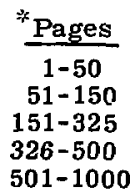

NTIS Selling Price

$\$ 4.00$

$\$ 5.45$

$\$ 7.60$

$\$ 10.60$

$\$ 13.60$ 
TID-4500, $\mathrm{LC}-32$

Mathematics and Computers

\title{
迆 \\ LAWRENCE LNEAMOFE LABORATORY
University of Calformis/Livormore, Caltomia/94550
}

\section{UCRL-5I742 \\ REDUCED, A DATA REDUCTION CODE}

\author{
Neil Maron
}

MS. date: January 22, 19'5

NOTICE

This repon was prepared $353 \pi$ socoupr of work

sowncuyes by the Unised Stales Guvernmsnt. Neither

the United States nor the United States Encrey

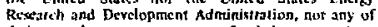
their anplayees, not any of their cemtactors,

subcontrdetors. of theis cmployees. makes any

messanis, express of implied, os asiumes any legal

teathity or tesponsibility fot the Jceuracy, completeness

or uscrumess of any informetion, 3pparbles, product at

foteess disctosed, ar reptesents that ils use would not

infming pivately owned rizhts. 


\section{Contents}

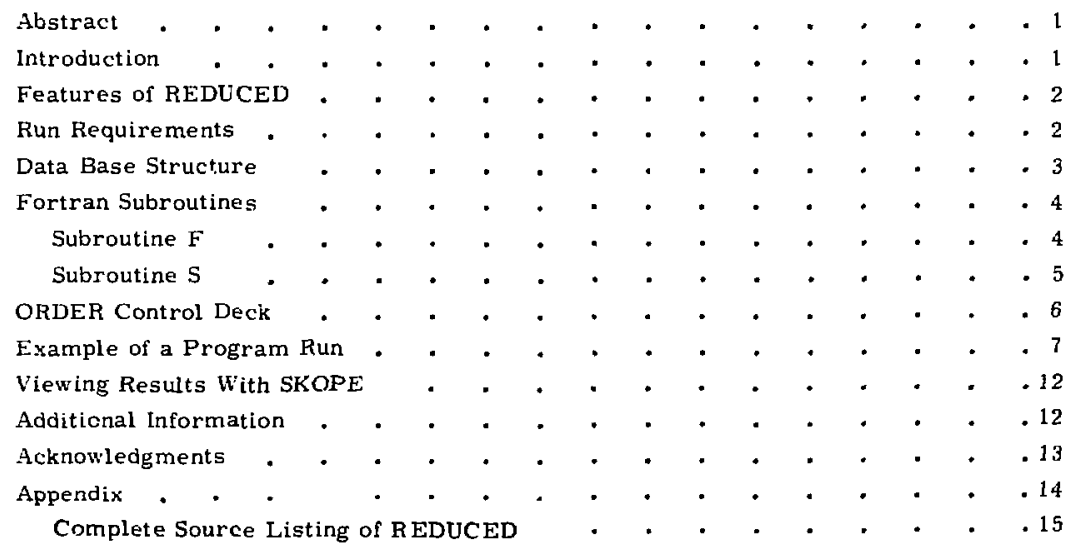




\title{
REDUCED, A DATA REDUCTION CODE
}

\begin{abstract}
REDUCED, a Fortran program currently running on a Lawrence Livermore Laturatory (LLL) CDC 6600, provides a simple means of accumulating a large base of experimental data (up to 21 parameters for up to 500 experiments) and interactively making two-dimensional plots of any pair of functions of the parameters. For each experiment, cach pair of function values is displayed as a discrete point. Linear or quadratic least-squares fits to the array of these points can be drawn. Results can be displayed on a variety of output media including printer/plotters, COM and CRT devices. Liser inputs required include a data base of parameter values; specification of functions to be performed; specification of symbols to appear on the actual plots; and necessary control cards. This report includes a description of REDr CED, instructions on how to use it, and a source listing of the complete code.
\end{abstract}

\section{Introduction}

A typical experiment in, for example, plasma physics would produce values of many raw parameters such as density, temperature, magnetic field, etc. for many runs. Physical effects would be identified by correlating dimensionless functions of these raw parameters, such as the ratio of plasma pressure to magnetic pressure, ion-to-electron temperature ratios, etc. The REDLCED program provides a simple means of accumulating a large base of experimental data ( $\leq 21$ parameters for $\leq 500$ experiments) and then interactively making two-ciimensional plots of any pair of functions of the parameters. For each experiment, each pair of function values can be displayed as a discrete point. The user can then request REDUCED to draw lit.oar or quadratic least-squares fits to the array of these points. ${ }^{1}$

In addition to providing a quick and effective way of examining experimental resuits, REDUCED also can interact $w$ ith the LLL SKOPE program, thus permitting observation of results on a CRT. The connection routine to SKOPE is via the LLL Fortran subroutine TVOUT.

The user must supply four types of input in order to use REDUCED. These are:

1. A card-format data base of the parameter values to be used.

2. A simple Fortran program (prepared by the user) defining all his desired functions. This allows the user to group data as required for his needs.

1. T. C. Varljen, General Linear Least Squares, Lawrence Livermore Laboratory, CIC lieport E2,2-005 (1967). 
3. I simple Fortran program thetining the symbols to be used on the plots of the paramelers. This program allows the selection of sereral different types of plot symbols in weder to identify such things as various groupings of runs, itc.

t. Afile of control eardi fir running the program. This report describes the uste of control cards tor the LLL ORll:k system.

This report provides a description of the Lawrence Livermore Laboratory's Implementation of lef:l] [ ( $1: 1)$, gives an explanation of its use that includes step-bystep examples, and supplites as an appendix the program's complete source listing.

\section{Features of REDUCED}

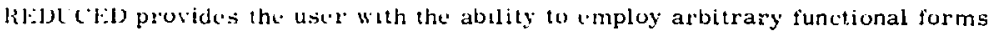
of the rall parameters $\left\{p_{i}\right\}$ ior both the abscissa variable $X: X\left(\left\{p_{i}\right\}\right)$, and the ordinate variabl. S Silp $\}$. Four types of tits are avallable: log-linear, litear-log, $\log -\log$ and linedr-linear. The user may then plot the results on any one or more of $12 \mathrm{grid}$ 1.pex. The liset also has the ability to specify a plotting symbol as a function of one of mure withe parameters. Linuar and quadratic tits of the $X-Y$ pairs are provided atutumatically: LP to four constants in functions (c. g., $X=1 \log (P(2)))^{C(1)}$ where C(1) $1:$ the first constant) are avalable to be varwed at run timc. Finally, the resulting graphs which appear in deleo filles may be velwed on the LLL COC: Gtioo "G"-machine CHT scopes during the run.

\section{Run Requirements}

The following ale required in order to periorm a complete run using H:DLCED:

i. The latelcell) program file itself, in the LLL system described in this

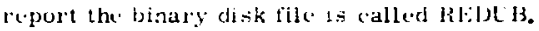

2. The datu bast file of input parameter values (called BASt.2) in the present system). See below under the heading bata base structure.

3. A liortran program defining the function to be usid (designated as subroutine l. of the disk file fircs in the present system). See below under the heading Fortran houtines.

4. A Fortran program defining the plotting symbols to be used (designated as subroutine $s$ of the disk tile fNCS in the present system). See below under the heading fortran Routines.

5. A disk file (designated $H A C$ in the present system) containing control cards for the LLL ORDER system. Sel below under the heading ORDER control I) cek. 
Thus, to actually run the code the following illes must be on disk: (1) REDLB, (2) RUC, (3) BASl:2, (4) HNCS. The user then types the following on line on the LLL system: ORDElR RDC / $\mathrm{t} v$. The following is a sample of what will result:

$\Rightarrow[1) \quad 452 \mathrm{MNH} \quad 9.34 / / 001 \quad 07 / 0914.398 \mathrm{RENLCLD}$ [3OX LO5

CONIJIL:

LOADING

CODI: ISLOC

CODE BLOC

RELLCEU H RITTEN

FILF: SLLE: $\quad 0106521$

FLD LGTH $=0106121 \quad 0106121$

EXECLTION

For an example of how the user interacts with code see the heading sample liun.

\section{Data Base Structure}

The core storage, as progranmed in RELLC:LL, allowis for 500 sets of 21:" parameters. The data base disk file, BASl:2, must have the following card forrat:

Columns 1-5: the experimental run number, right justifl:-d, value: i" 500

Columns 6-10: the card number of the run, right justified, value 1-3

Columns 11-80: 7 F10.0 noating point entries of parameter values.

The cards need not be in order of run because the program jorts on the informatiun in columns 1 to 5 and 6 to 10 to determine this order. Card 1 of each run contains parameters 1 to $i$, card 2 of each run contains parameters 8 to lt, etc. Al parameters need not be given ar once or even on a single set of three sards per run. The last card of the data file must always have $a-1$ in coimmns $t$ and $a$ (using an 11 punch in column 4 for the minusl. If it is desired to correlate the jun number with the parameter of a run one of the parameters must be the floating point run number. The subroutines $F$ and $s$ cals then sort on the run number and group the output accordingly.

certain parameters wall be neasured in some runs but not in others. For the runs in which a parameter is not measured enter a 0 . but do NOT leave the entry blank. Only leave blanks for eintries that are never usert. This, if only ten parameters are measured, columns 11 through $1 \mathrm{t}$ of the second card can be left blank and the third card can be omilted. Table 1 is a sample listing of a data base tile made up of 2 cards per run, 5 runs, and 8 parameters per run. 
Table 1. Sample data basi.

\begin{tabular}{|c|c|c|c|c|c|c|c|c|}
\hline \multirow{2}{*}{$\frac{\text { tiun }}{\text { No. }}$} & \multirow{2}{*}{$\begin{array}{l}\text { Card } \\
\text { No. }\end{array}$} & \multicolumn{7}{|c|}{ Gittries 1 through 7} \\
\hline & & 1. & 2.7 & 3 & 0.02 & 1. & 0. & 4. \\
\hline 1 & 3 & 101.1 & & & & & & \\
\hline 2 & 1 & 2. & 2.4 & 0. & 0.11 & $\therefore$. & 36. & $\bar{~}$ \\
\hline 2 & 2 & $10 \geq .4$ & & & & & & \\
\hline 3 & 1 & 3. & 2.15 & 2.8 & 0.15 & I. & int. & 4. \\
\hline 3 & 2 & 102.0 & & & & & & \\
\hline 4 & 1 & f. & 2.6 & 2.7 & 0.17 & 2. & iti. & 4 \\
\hline 4 & 2 & 101.7 & & & & & & \\
\hline$j$ & 1 & 5. & 2.3 & 2.5 & 0.19 & l. & $\therefore$. & t. \\
\hline 5 & 2 & 101.1 & & & & & & \\
\hline-1 & & & & & & & & \\
\hline
\end{tabular}

\section{Fortran Subroutines}

scistrol Tixi. 1:

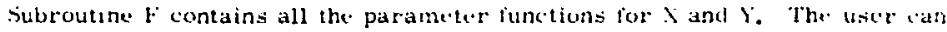

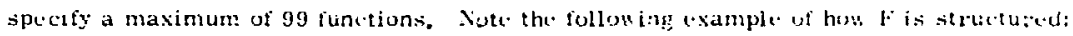

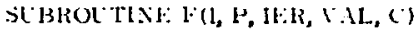

DIMH:XION 1.21), (

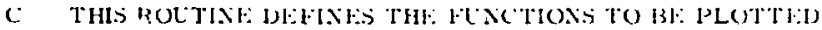

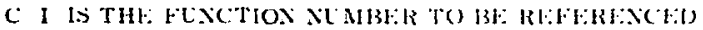

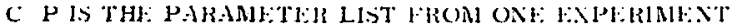

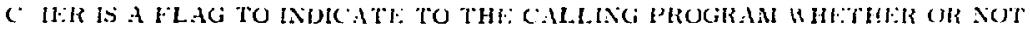

c TULSE TH: VALLF IIITLRX

c 0 MHAXS ISL VAL UN GRAPH

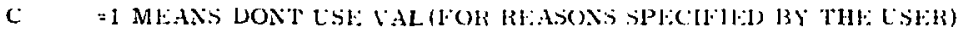

C VAL IS THE: VALLLE RHTLREL

C C LS THE ARRAY OF FOCR CONSTANTS

$1 \mathrm{H}: \mathrm{R}=\mathbf{0}$

J $=\mathrm{I}$

IF(J. GT. 10) GO TO Jis]

GO $T \cup(1,2,3,4,5,6,7,8,9,10), \mathrm{J}$

FIXI $\mathrm{J}=\mathrm{J}-10$

IN (J. GT. 10) GO TO F.LX2

GU TO $(11,12,13,14,15,16,17,18,19,20), \mathrm{J}$

FIX2 $\mathrm{J}=\mathrm{J}-10$

etc. 
If the value of a parameter is 0 . it is assumed to be a blank entry and is not used, so this . ondition must be checked for. Note the following:

$1 \mathrm{HW}(\mathrm{HL} ; \mathrm{EQ} .0$.$) GO TO FRR$

$\because A L=P(2)$

หน, I k

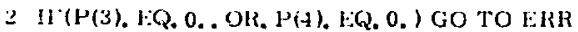

$\therefore A L=I+(3) / P(4)$

RETI RN

etc.

¿ THIS SHOWS iHF CSF OF THF C ARRAY. CHECLING FOR C BEING SOME: VALUF

(c IS OT.TIONAL

10 IF(1)(2). H:Q. 0. . OR, P(5), EQ, 0. . OR, Cil), GT, 1U.) GO TO FRR

$\therefore A L=(P(2) / C(1)): \because 4 \cdot P(5)$

RH:TIRN

itc.

FKK II:K =

RE:TLRX

(:Ni)

Intermediate values can be checked to give a 'don't use' return also. Note the following:

15 IF(1)(3). HQ. 0. . OH. P(3). KQ. 0. ) GO TO ERR

TEMP $=12(2) / P(3)$

IFIT1:M12. G1: 1.! GO TO ERR

$\because A L=(-L O G(T H M P)):: 2$

RI:TCRX

At run tiwe the user will be seked for the function numbers corresponding to $X$ and $\psi$,

These numixers are the val "us of " $\mathrm{l}$ " and "J" "lien interacting with the program.

\section{SLBROLTINF: S}

Subroutine $\$$. contains the parameter functions for determining the symbols used in the actual plots. The structure of is is shown in the following example:

SLHROL'MNE: S(I, P, lJ:k, SYM)

DIMESTION $\mathrm{P}(1)$

C THIS ROLTINE DEFINES SYMBOLS THAT WILL APPEAR ON THE PLOT

C: I IS THF: FCNCTION NCMBER

C. PIS THE PARAMETER LIST FROM ONE EXPERIMENT

C. IER IS A IFAG TO INIDICATE TO THE CALLING PIROGRAR WHETHER OR NOT TO

C LSE THIS RUN FOA FITTING AND PLOTTING

C. $=0$ MHEANS LSE RIN AND PLOT SYMBOL RETURNEIJ

C $=1$ DONT LSE RUN

C SYM IS SYMBBOL RETCRYEI) 
IE $R=0$

$\mathrm{J}=\mathrm{I}$

IF (J. GT. 10) GO TO FIX1

GO TO $(1,2,3, \ldots$ tc. $)$

From this point, follows the same pattern as subroutine $F$.

1 IF(P(2). EQ. 0.' GO TO I:RR

$S Y M=1 \mathrm{H}-$

IF(P(2). LT, 10.) SY $M=1 \mathrm{H}:$

$1 F(P(2)$, GE, 10. . AND, $P(2), L T, 20$.$) SYM =1 \mathrm{H+}$

C WHEN THE PLOT IS MADE, THE ABC i

C THAN 10, THE SYMBOL + FOK P2 BETWEEN 10 AND 20

C AND THE SYMBOL - FOR P2 GREATER THAN 20

RETURN

etc.

ERR $[E R=1$

RETURN

END

When it is desired to use onI: a single plot symbol (e. g. a $\%$ ) a simplified program can be used, as in the following example:

SUBROUTINE S(1, P, IER, SYM)

DIMENSION $P(1)$

IER $=0$

$S Y M=1 \mathrm{H}:$

IRETURN

END

\section{ORDER Control Deck}

To increase ease of running, the followirir control deck for ORLEH, the LLL special batch processor, ${ }^{2}$ must be supplied in the order tiven. This is the disk file RDC (five cards).

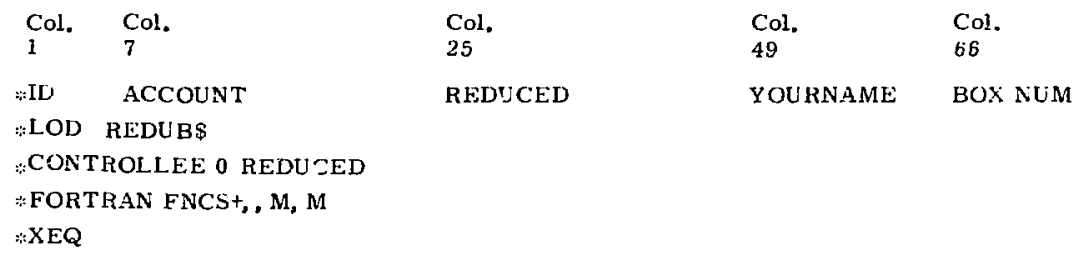

2. R. Potter, The ORUER System, Lawrence Livermore Laboratory, Rept. LTSS-202 (1972). 
AccotiNe is the LL. Uner's accotint number, NLN is the user's LL.L box nurnber.

\section{Example of a Program Run}

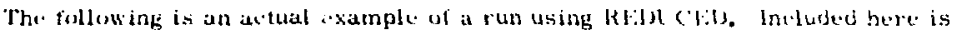

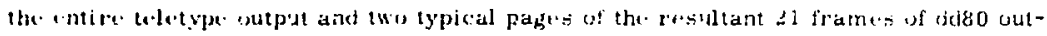

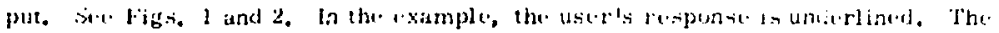
cemments on the right have been added to aici in readeng the axumpde.

The macha response HOW MANY HkACk!:TS? is asking for hon nany subert: of the data as to tse thede. If all the datid are to be used for fitting, then 01 is the response. If runs $I$ to 13 and run 18 are to be used, then the resposse is 02 , cte. A single run isoliated from others constitutes I subsel or tirarket.

I3OX ANI) (i)

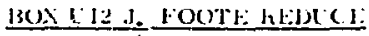

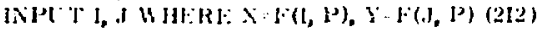

1,116

INPCT K UH:RK: PLOTSYMES(K, $l\},([2)$

$\underline{0 \mathrm{i}}$

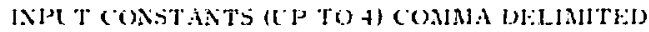

$\dot{-}$

HOW MANY BIPACKI:TS? (12)

$\underline{02}$

INPLT BKACKFT LINIT', 3 PAIKS/LINE (613), FOLLUWING OK

UK 1 OH I TO2

001162200232

I96 VALID POINTS, PLOT? Y OPN

$\underline{Y}$

INPUT TITLE, 72 CHARS MAX

K-PERPENDICULAR VS GYRORADIUS (ALL BBI AYD BBII DATA

INPUT $X$-LABEL, $40 \mathrm{CH} A \mathrm{RS} M A X$

GYRORADIUS (CM)

INPUT Y-LABEL, 40 CHARS MAX

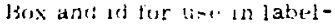
ing polut:

Furtran ir.rmats for input values are in partatheses at s: near end of lines. These are input ralues of $P$ in subruatine $r$.

$18=1,16-1$

These ire the valles of $\mathrm{P}$ in subroutine 5 .

Thest are values of $\mathrm{C}$ in stobruutine $F$.

Mlust end uith a comrna. In this casce, nome are specifiecd.

This feature allows one to fit sections of data and $\mathrm{cx}$ clude others,
Prusram now processes data set.s 1-162 and 200-233. This response tells how many lalid data points were found to be fit.

Title for plot (sce Fig. 1). 


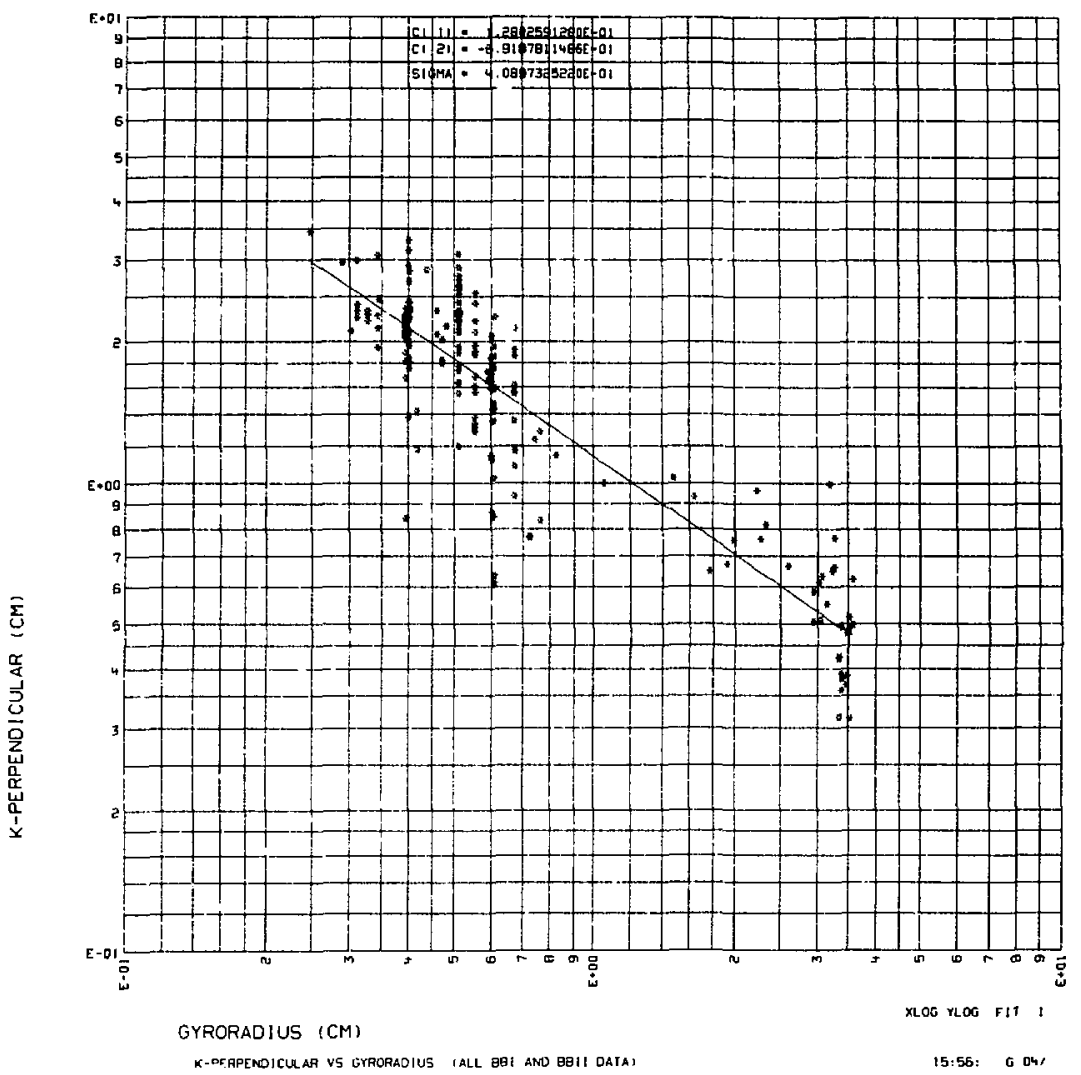

Fig. 1. Typical plotted output of data processed by REDUCED. 
XLOG YLOG FIT I

\begin{tabular}{|c|c|}
\hline $\begin{array}{ll}\text { C1 } & 11 \\
1 & 31\end{array}$ & $\begin{array}{r}\text { 1. } 2600591200 E-01 \\
-6.91879 / 1485 E-01\end{array}$ \\
\hline
\end{tabular}

FSTIARTEO STO DEV

$3.35703315456-02$ $4.0419927005 \mathrm{E}-02$

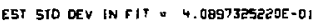

INOEPENOENT YAF] ABLE
GKRORADIUS (ET)

5.1180933ะsar +e1 5.110093seser 4. $02004995325-01$ 2. $8992791301 \mathrm{tE}-01$ 2. $4095479200 E-01$ $4.393030104 \mathrm{EE}-0$ ? 3.457409543...E-01

6. $129909+4635=01$ $3.4723924465 \mathrm{E}-01$ 4. .2429230605-01 5. $1190933258 \mathrm{e}-01$ 5. $1160933558 E-01$ 5. $0136907064 \mathrm{E}-01$ 6. $0136907084 E$ - 01 5. $1100933258 E-01$ 4.0280495533E-01 3. $12837300895-01$ 5. $1180933258 E-0$ 5. 1 1 $90933258=-0$ $4.0280499535 E-01$ $4.026 U 499533 E-01$ 1. $0280499533 E-0$ i 3. $13637300095-0$ $5.11609332585-0$ $4.0260499533 z-0$ $3.12637300986-01$ $4.0290499533 \mathrm{E}-01$ 5. I16093325BE-01 6.0136507094 - 0 5. $11809332585-0$ 5. $1180933258 E-0$ $6.7344137326 \mathrm{E}-01$ 1. $4662607995 \mathrm{0} \cdot 00$ i. $0555650467 \mathrm{E}+00$ 5. 1 !809332505-01 7. $4641+34462 E=0$ 6. $0461178043 E-01$ B.2716056987E-0I 7.6580180! 335-01 7. $2380769948 E-01$ $7.23507699+a E-01$ 6. 0461 17904 3E-0 $6.04651780435=0$ 4. $02904995335-01$ $4.0200499535-01$ 3. $4531919441 E-01$ 5. $11809332586-0$ 5. 1190933258E-a1
DEPENDENT YARIAELE K-PERPENDICULAR (CM)

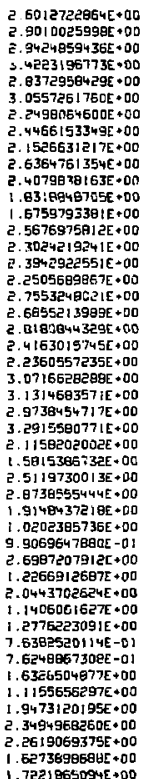

HE IGHIS

CACWHAIED Y

$1.0000000000 E+00$

1. MOOOOGOONOE $\rightarrow 00$

1. $0000000000 E+00$

$1.0000000000 E * 00$

$\therefore .0000000000 \mathrm{E}+00$

$1.00000000005+00$

1. $00,0000000 E+00$

1. $0000000000 E+00$

i. $.0000000000 E+00$

1. $0000000000=00$

$1.0000000000[+00$

1. $0000000000 E+00$

1. O0DaOODDODE +00

1. $00006000006+00$

1. $00000000005 * 00$

1. $0000000000 E+00$

1.0000050000 e +00

1. $0000000000[\circ 00$

1. $.0000000000 E+00$

$1.0000000000 E-00$

1. $0000000000 E \div 00$

$1.0000000000 \Omega+00$

1. $6000000000 \mathrm{E}+00$

1. $0000000000+00$

1. $0000000000 E+00$

$1.0000000000 E+00$

1. $0000000000 \mathrm{E}+00$

1.0000 CBNDOCE +00

1. $0000000000 E+00$

1. $000000000[\div 00$

$1.0000000000+00$

$1.00000000005 \cdot 00$

1. $0000000000 \mathrm{E}+00$

1. $0000000000 \mathrm{E}+00$

I. $0000000000 \mathrm{E} \div 00$

$1.0000000000 E+00$

1. $.0000000000 \mathrm{E}+00$

1. $0000000000 \mathrm{E}+00$

1. $0000000000 \mathrm{O}+0 \mathrm{D}$

1. $0000000000 E+00$

1. $0000000000 \mathrm{E}+00$

1., $0000000000 E \cdot 00$

1. $0000100000 E * 00$

1. $00000000035+00$

1. $00000000000 \div 00$

$1.0000000000 \mathrm{O}+30$

1. $0000000000 \mathrm{C}+00$
1. $.00660254206 \cdot 00$ 2. 1 자.1962723E+00 2.6768911278E+00 $2.9753131705 E+00$ 2. $0090040924 E+00$ 2. $36999528655+00$ 1. $594 \in 366256 E .00$ . $3629155775 \mathrm{E} * 00$ 1. $8920209380 \mathrm{C}+\mathrm{CO}$ $1.906602542 E E+00$ 1. $0066025428 L^{2}-00$ $1.6159758591 E+00$ $1.61567505915+00$ 1. Bo66025420 +30 2. $13219627235+00$ 2. $5408039998 E+00$ 1. $.60660255+28 E+00$ 1. $.0066025428 C+00$ 2. $13219627335+00$ $3.1331963) 35+00$ 2. 2. $1321562723 E+00$ 2.54000399Res-00 $1.8066025428 E+00$ 2. $1321962723 \mathrm{E}+00$ ट. $5408039986 \varepsilon+00$ ‥ 13219627235400 I. 80650254 $28 E+00$ 1. $6158758691 \mathrm{E}+00$ 1. $.0065025428 E \div 00$ 1. $0065025420 E+00$ $1.49415813025+00$ 8. E403665546E-OI l. 09482951345400 1. $8066025428 \mathrm{R}+00$ l. $3915042245 E+00$ 1. $60901628245 \times 00$ 1. $2960410128 \mathrm{E} \cdot 00$ 1. 76703055705 1. 1. $4214270772 E 400$ 1. $4214270722 E+00$ 1. $60997626 \mathrm{E}^{2} \mathrm{E} \cdot 00$ 1. $609876 \mathrm{~F} 8 \mathrm{~B}$ บE $० 00$ द, $13219627235 \bullet 00$ 2. $13219627235+00$ 2. $3718975464 E+00$ 1. $8066025428 E+00$ 1. $80660254285 \cdot 00$

Fig. 2. Example of tabulated output data processed by REDUCHD. 
K-PERPENDICULAR (/CM)

DO YOU WANT HELP FOR FIT TYPES? Y OR $N$

$\underline{Y}$

1 XLIN YLIN FIT

2 XIIN YLOG FIT

$3 X L O G$ YLIN FIT

4 XLOG YLOG FIT

INPUT FIT TYPE (I1)

$\underline{4}$

HOW MANY DIFFERENT PLOT GRIDS? (1 TO 12) (12)

$\underline{01}$

DO YOU WANT HELP FOR GRID TYPES? Y OR N

$\underline{Y}$

NO GRID FULL GRID PARTIAL GRID

$\begin{array}{lllllll}X & Y & X & Y & X & Y\end{array}$

1 LIN LIN 5 LIN LIN 9 LIN LIN

2 LOG LOG 6 LOG LOG 10 LOG LOG

3 LIN LOG 7 IIN LOG 11 LIN LOG

4 LOG LIN 8 LOG LIN 12 LOG LIN

INPUT GRID TYPE (1) (12)

$\underline{06}$

DO YOU WANT TO VIEW ON SKOPE? Y OR N

$\underline{\mathrm{Y}}$

MONITOR NO. ?

.$\underline{100}$

TYPE DD80 FILENAME

- BBIIX

CAN'T OPEN FILE

TYPE DD80 FIL.ENAME

- BBIIY

.$\underline{5} \underline{4}$

. $\underline{\mathrm{S} 2}$

-

- END

SKOPE DONE

INPU T

$1 \mathrm{NEW} F(X), F(Y)$

2 NEW FIT TYPE

3 NEW CONSTANTS ONLY

4 NEW CONSTANTS, BRACKETS ETC

5 MORE PLOT GRIDS

6 END
This allows user to view results at run time.

Error because this is not the filename while REDUCED is running.

This is the correcl response.

REDUCED now asks if user wants to continue or end. 
INPUT I, $J$ WHERE $X=F(I, P), Y=F(J, P)(212)$

$\underline{1617}$

INPUT $\mathrm{K}$ WHERE PLOTSYM=S(K, P), (I2)

$\underline{01}$

INPUT CONSTANTS (UP TO 4) COMMA DELIMITED

1.7, 3E7,

HOW MANY BRACKETS? (I2)

$\underline{02}$

INPUT BRACKT LINITS, 3 PAIRS/LINE (6I3), FOLLOWING OK

OK FOR 1 to 2

$\underline{00+162200233}$

196 VALID POINTS, PLOT? Y OR N

$\underline{\mathrm{Y}}$

INPUT TITLE, 72 CHARS MAX

K-PARALLEL VS K-PERPENDICULAR (ALL BEI AND BBII DATA)

INPUT X-T.ABEL, 40 CHARS MAX

K-PERPENDICULAR (/CM)

INPUT Y-LABEL, 40 CHARS MAY.

K-PARALLEL (/CN)

DO YOU WANT HELP FOR FIT ${ }^{\cdots}$ ' $>$ ' Y OR N

$\underline{N}$

INPUT FIT TYPE (I1)

$\underline{4}$

HOW MANY DIFFERENT PLOT GRIDS (1 TO 12) (12)

$\underline{01}$

DO YOU WANT HELP FOR GRID TYPES? Y OR $N$

N

INPUT GRID TYPE (1) (I2)

$\underline{06}$

DO YOU WANT TO VIEW ON SKOPE? Y OR N

$\underline{\mathrm{N}}$

INPUT

1 NEW $F(X), F(Y)$

2 NEW FIT TYPE

3 NEW CONSTANTS ONLY

4 NEW CONSTANTS, BRACKETS ETC

5 MORE PLOT GRIDS

6 END

$\underline{6}$

ALL DONE 
When finished running, two files resulting from this run will be present in the user's private files. These are: BBIIX (the dd80 plot file) and TAPE3 (the HSP file containing the same numbers as those on the dd80 file). To get microfiche and hardcopy of the BBILX file on the LLL system, execute:

FROG BBILX DDB0. / 2.2

After this, BBIIX will be gone from the disk. To get hardcopy of TAPE3 execute:

ALLOUT HSP TAPE3 BOX LNN YOURID / 1.1

LNN is the user's LLL box number and YOURLD is 20 characters of user identification information that will appear on the file.

\section{Viewing Results With SKOPE}

To view the resulting files on a CRT scope, REDUCED uses the utility routine SKOPE. ${ }^{3}$ If the user replies YES to the program query: DO YOU WANT TO VIEW ON SKOPE?, then connection is made to the SKOPE rontine. To get back to running REDCCED, type CONT (linefeed) on the teletype. The next time that SKOPE is running, the word CONT is types back to the user as a prompt. The only two features of SKOPE that can't be used are its GO and GIVE options. Be sure to be familiar with the SKOPE routine before attempting to use this feature of REDUCED.

\section{Additional In formation}

For those interested in using REDUCED for their applications, a source version of REDLCED or the corresponding binary version (i.e. REDLB) may be obtained from the author. Those interested in applications or simply in obtaining additional information on this program, can contact the author at the following address:

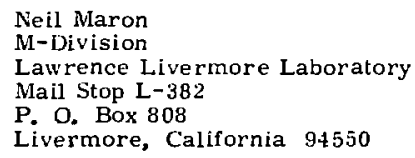

3. B. Thornquist, D. Fuss, B. Howard, N. Maron, SKOPli, Lawrence Livermore Laboratory, Rept. UR-422, Revision $1(1974)$. 


\section{Acknowledgments}

The author would like to thank B. MeNamera for suggesting the preparation of this report which will hopefully be a useful aid to the experimentalists of the LLI. M-Division and to others. Also, many thanks to J. Foote for his use of this package in its developmental stages as well as his suggestions for specific features. 


\section{Appendix \\ COMPLETE SOURCE LISTING OF REDUCED}


PROGRAM REDUCEDITAFE59, TAPE I 00, TAPE 3, TAPE5,BASE $2=$ TAPE5)

C
C
C
C
C
C
C
C
C
C PROGRAM: REDUCED

PROGRAMMER: NEIL MARON (FOR DRIVER OF GLS)

DAIE THIS VERSION: OBDECI974

C NVAR MUST BE A MULTIBLE OF 7

C NRUN SHOULD BE EQUAL TO THE PARAME TER NF

NRUN = TOTAL POSSIBLE RUNS ALLOWED IN DATA BASE

C NVAR = MAXIMUM NUMBER OF VARIABLES PER RUN ALLOWED

PARAMETER (NRUN $=500, N V A R=21$ )

DIMENS I ON CORE (NRUN, NVAR), BUF ( 7$), K O N(30), F C(2), M N B R$ ( 99$), M X B R(99)$

DIMENSION X(NRUN), Y(NRUN), PRM (NVAR), XLAB 77$), Y L A B(\%), C A L C O N(4)$

DIMENSION Mj(14),MT (B), MU (23)

COMMON, GOBCOM/ [B(4])

COMMON/LABELS/T I TLE (10), XTI15), YT I15,

COMMON/ISYM/SYM (NRUN)

COMMON/SKOPEON/ISONO

C HELP MESSAGES TO BE ISSUED WI TH SYSTEM CALLS

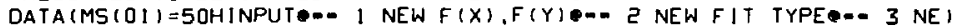

DATA $(M S(O 6)=50 \mathrm{HW}$ CONSTANTS ONLYE $\rightarrow-4$ NEW CONSTANTS,BRACKETS ETC -1

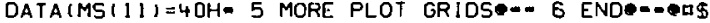

DATA $(M T(O I)=50 H]$ XLIN YLIN FIT--2 XLIN YLOG FITE--3 XLOG YLIN FII)

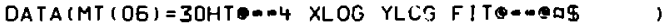

DATA(MU(O) $)=50 H$ NO GRID FULL GRID PARTIAL GRID*a $X$ Y ।

DATA(MU 06$)=50 H \quad X$ Y $X$ YO-OILIN LIN 5 LINLIN

DATACMUIII: $=50 H$ LIN LINA--? LOG LOG 6 LOG LOG 10 LOG LOGeDS 1

DATA(MU(I6) $=50 H=-3$ LIN LOG 7 LIN LOG $1 !$ LIN LOG $=-4$ LOG LIN I

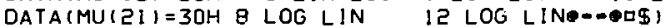

C OPEN DATA BASE

CALL DEVIC̈̈ (4HOPEN.5HBASE2. LEN, IER, IOC, LEV)

IF (IER.EQ.O) GO TO I

C INFORM THAT DATA BASE CANT BE OPENED

WRITE (59,2)

2 FORMAT (2OH CANT OPEN DATA BASE)

CALL EXIT

C READ IN DATA AND SORT INTO CORE

I DO $3 \mathrm{~J} i=1$, NRUN

DO $3 J Z=1$. NVAR

3 CORE $(J 1, J 2)=5$.

4 READ $(5,6)$ NF. NC, (BUF (1), $1=1,7)$

6 FORMAT $(15,15,7 F(0.0)$

IF (NR.LT.1) GO TO 10

$I=N R$

(FII.GT.NRUN) GO TO 8

IF (NVAR/7 .LT. NCI GO TO B

DO 7 IVAR $=1,7$

$J=7 *(N C-1)+j, \quad$ AR

CORE ( I .J) =BUF ( IVAR )

7 CONTINUE

GO TO 4

C INFORM THAT EITHER THE RUN NUMBER OR THE NUMBER

C OF PARAMERERS IS TDO LARGE

8 WRITE 59.91

9 FORMAT (30H DATA BASE ENTRIES EXCEED CORE)

CALL EXIT

10 CALL DEVICE (5HCLOSE, 5HBASE2, IER, IOr.)

C ASK FOR BOX AND IO INFORMATION FOR PLUTS

WRI TE $(59,5)$ 
5 FORMAT ( $10 \mathrm{HBOX}$ AND ID)

READ (59,120) (iB(J), J=36.38)

120 FORMAT (3A1O)

CALL CRTIOIEHNM, I)

CALL KEEPGO(SRBBIIO)

I $\mathrm{CON}=0$

$c$

C

35 WRITE (59.11)

1) FORMAT (40H INPUT I,J WHERE $X=F(1, P), Y=F(J, P)(212)]$ READ (59,12) IFX, IFY

IC FORMATIEIz:

$C / 1$ LOOP FOR SETTING UP $X-S$ AND $Y-S$ WRI TE (59, 13)

13 FORMAT (35H INPUT K WHERE PLOTSYM=S:K,P), (I $)$ ) READ (59,12) ISYM

$3 B$ WRITE $(59,36)$

36 FORMAT ( 4 IHINPUT CONSTANTS (UP TO 41 COMMA OELIMITED) REAO (5E, 37) (CALCON $(J), J=1,4$ )

37 FORMAT ( $4 F 15.0$ )

IVAL ID-O

IF (ICON-1), 44 WRI TE $(59,40)$

40 FORMAT ( 23 HHOW MANY GRACKETS? (12)

READ $(59,76)$ NBRK

$\mathrm{NI}=\mathrm{NBRK} / 3$

$[F($ INI 3 i. NE . NGRK) $\mathrm{N}]=\mathrm{N}]+1$

WFI TE $(59,41)$

41 FORMAT I53HINPUT BRACKET LIMITS, 3 PAIRSILINE (6I3),FOLLOWING OK)

C

C SEARCH DATA AND SET UP $X$ AND $Y$ FUR FITTING

C

$0045 \mathrm{JI}=1, \mathrm{NI}$

$J V=(J 1-1) \cdot 3+1$

$\mathrm{J} 3=\mathrm{Jl} \cdot 3$

IF ( J3. GT . NPRK) J3=NBRK

WRI TE $(59.42)$ J2.J3

42 FORMAT I 7 HOK FOR . 13,4H TO . 131

READ (59.43) (MNBR(1),MXBR(1), $1=J 2, J 3)$

43 FORMAT $(613)$

45 CONT INUE

44 DO : $3 \quad J 3=1$, NBRK

DO 20 JI=MNBR (J3 I, MXER (J3)

DO 21 JZ $\approx$, NVAR

PRM $(J E)=C O R E$ ( JI . JE)

21 CONT!NUE

CALL FIIFX,PRM, IER, VAL, CALCON I

IF IIER.EO. II GO TO 20

XIIVAL ID+ I I = YALL

CALL FIIFY, PAM, IER, YM, CHLCONS

IFIIER.EO. 11 GO TO 20

YIIYAL ID+ II = YAL

CALL SI (SHM,PRM, (ER,PSYM)

IFIIER.EO.1: 60 TO 20

SYMI IVAL IDI =PSYM

IVAL ID=IVAL ID.I

20 CONIINUE

19 CONTINUE

C NOTIFY OF HOW MANY VALIO POINTS FOR FIT-INO WERE FOUND 


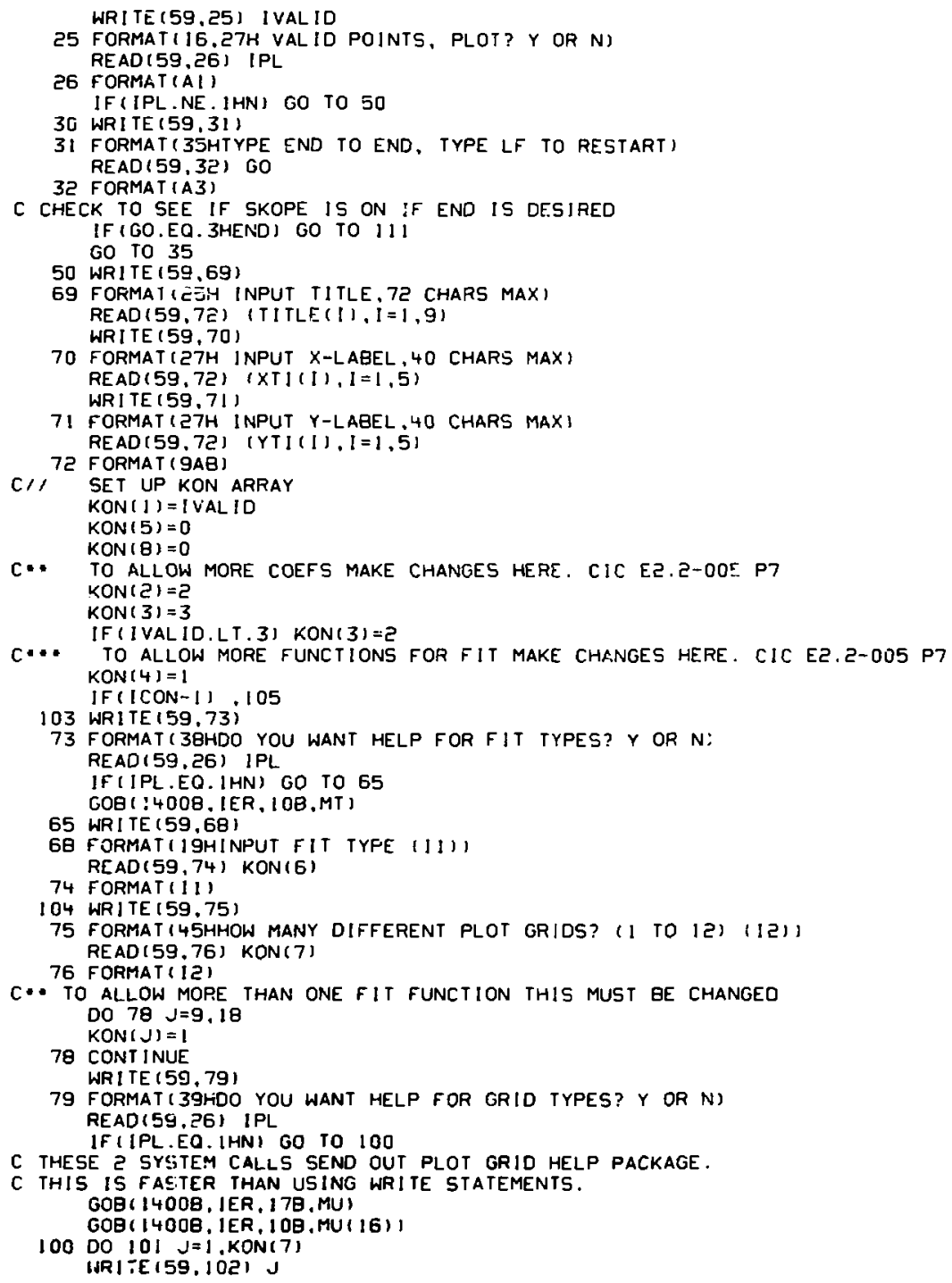




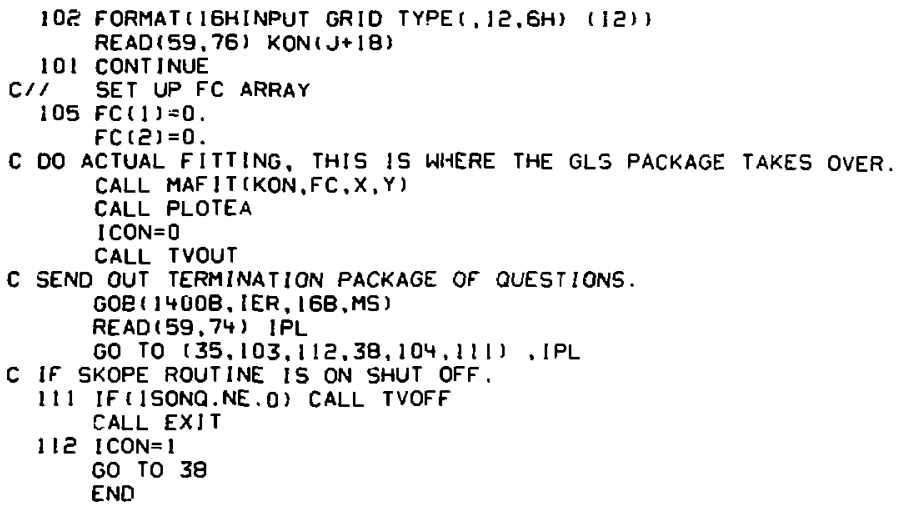


SUBROUTINE TVOUT

DIMENSION IB(15)

COMMON/ SKOPEON/ISONO

DATA \& IFL $=1$, , I SONO $=0$ ]

IF (IFL) CNT . . ASK

RET RETURN

C ASK TO SEE IF USER WANTS TO USE SKOPE

ASK $1 B(1)=10$ HDO YOU WAN

$I B(2)=I O H T$ TO VIEW

$1 B(3)=1$ HON SKOPE?

IB $(4)=1 \mathrm{OHY}$ OR $\mathrm{N} \cdots$

IB $(5)=$ OHEDS

GOB (1400B, IER, 5, JB)

C PICK UP REPLY

RCVI GOB (2000B, IER, I00B, IB)

IF (IB-IRN) INT .

$I F L=1$

GO TO RET

C SET UP BETA WORDS

INT $1 B(1)=5 R$ SKOPE.

$[B(2)=0$

$1 \theta(3)=0$

I ZERO $=0$

C ISSUE CONNECT

GOB (2Z00B. IER, I ZERO, IB)

I $5 O N O=1$

IF (IER-1) INTC,

C CONNECT FAILED ASK FOR RETRY

I SONO $=0$

!B $(1)=10 H C A N T$ START

$I B(2)=10 H$ SKOPE. RE

IB(3) = IOHTRY? Y OR

IB $(4)=1$ OHNE - ODS

GOB $(1400 B$, IER, $4,1 B)$

GO TO RCVI

C START W/O MESSAGE

INTC GOB ( 1520B, IER, IZERO, IB)

C LOOP = GTME , SNMR , GTMR, SNME

C PICK UP SKOPES MESSAGE

LOOP GOE (1700B, (ER, 17008, 18)

IF IIB.EQ.777777777777777777778) GO TO INTC

IF (IB 1 OHE-C ALL DOI FIN

[F (IER-1) ,PCK

C SEND TO TTY

GOB (14008, IER, (78, (8)

C START W/O MESSAGE AND CHECK FOR MORE MESSAGES GOB (1520B, IER, I00B, IB) GO TO LOOP

CNT GOB I14008. IER. 178. (B)

C NO MORE MESSAGES SO PICK UP TTY NESSAGE

PCK GOB (IEO0B, IER, (7008, JB)

IF ( (IE. INT . 4H-D-A)-4HCONT I , JRE T

IF IIIB. INT, $2 H=1-2 H G O$, NOGO

C SEND TO SKOPE

GOB (1500B, IER, 1178, 18)

GO TO LOOP

NOGO IBIII=IOHCANT USE G

$I B(2)=10 H O$ OPT IONO-

$\{8(3)=10 H=$. ens

GO TO CNT 
JRET IE' $=-1$

GO TO RET

C INFORM THAT SKOPE IS DONE AND RESET FLAG

FIN $|B| 1]=10 H S K O P E$ DONE

$I B(2)=10 H Q-0.55$

GOB ( 14008, IER, 2, [B]

I $F L=1$

GO TO RET

ENTRY TVOFF

( $\mathrm{B}(1)=$ ) $\mathrm{BHENDE} \$$

GOB ( $1500 B, 1 E R, 1018,18)$

GOB ( I 7ODB, 1ER, 1700B, (B)

I $5 O N Q=0$

RETUFN TVOFF

END 


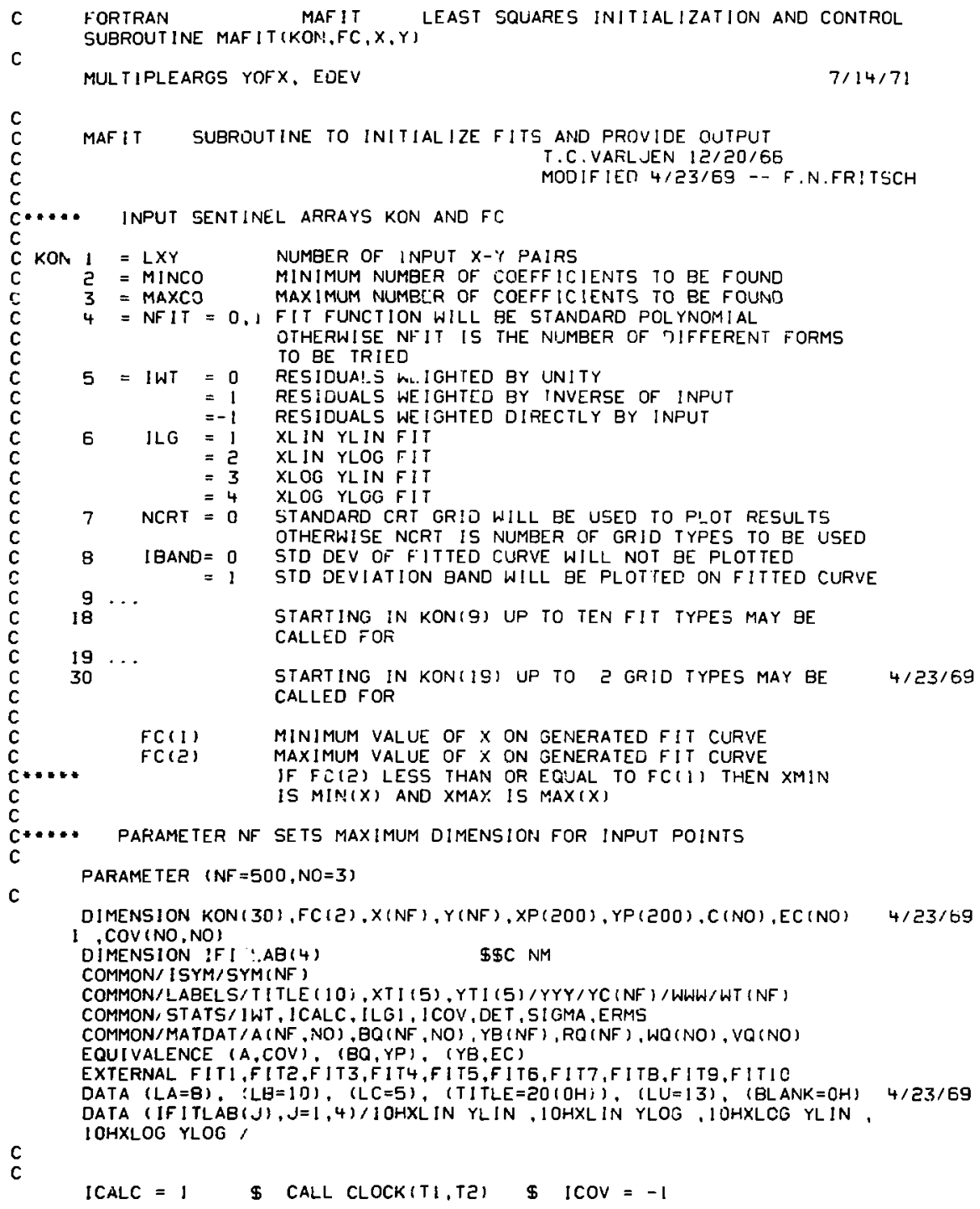




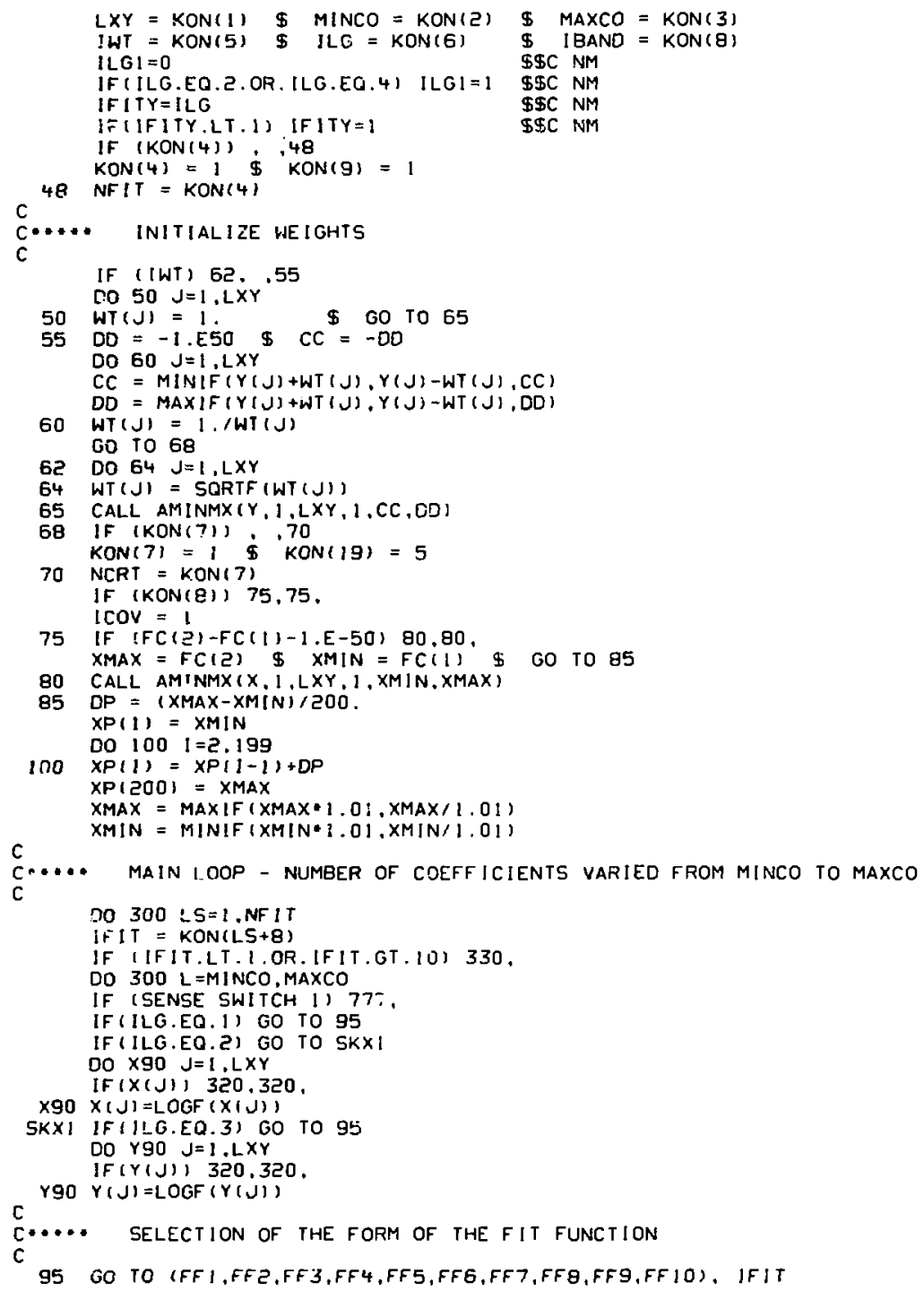




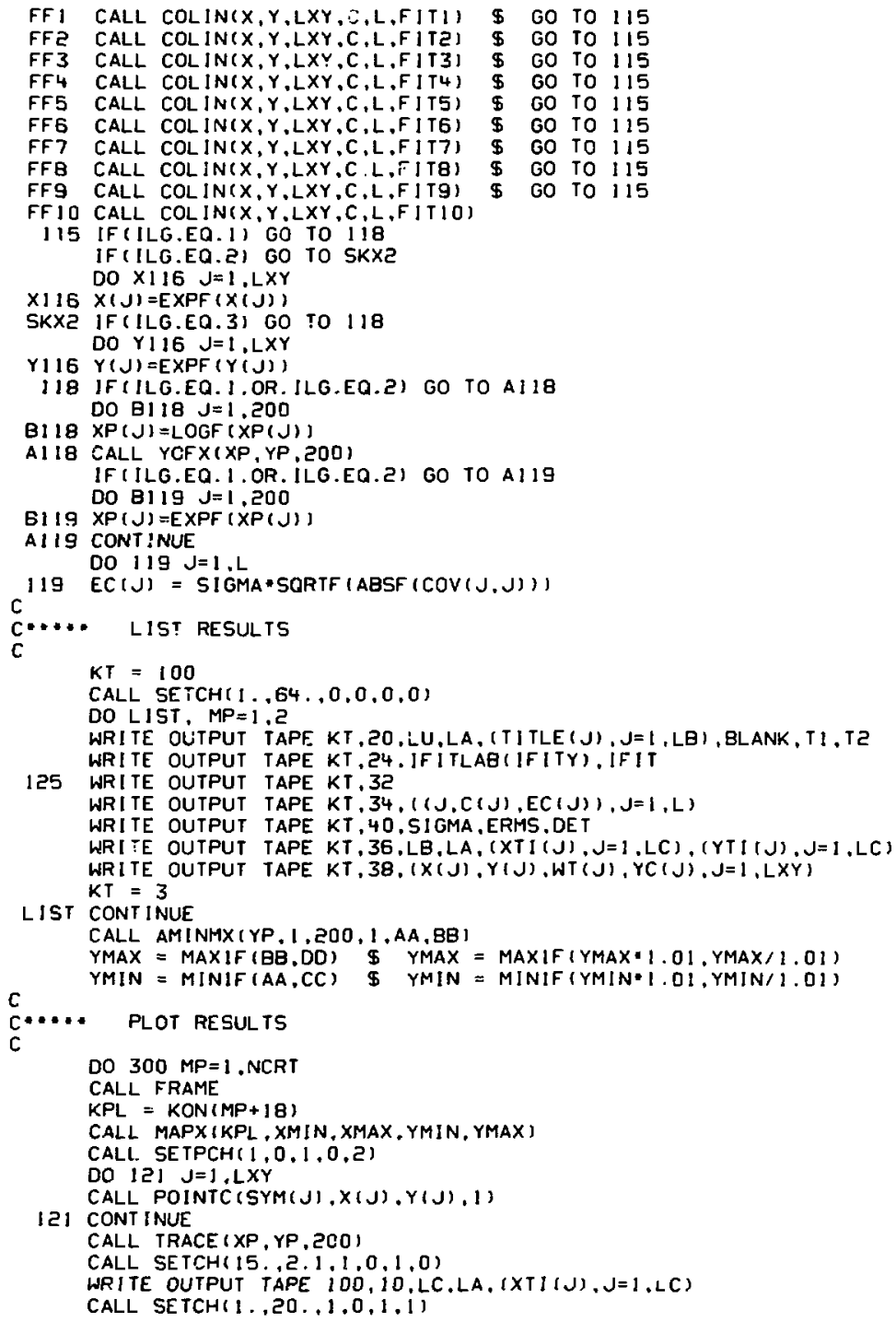


WFI TE OUTPUT TAPE $100,10, L C, L A,(Y T I(J), J=1, L C)$

$X L B=50$.

$Y L B=63.5$

DO $120 \quad K=1, L$

CALL SETCH(XLB, YLB, $1,0,0,0)$

WRITE CIITPI'T TAJE $100,45, K, C(K)$

120

$Y L B=Y L B-1$.

$Y L B=Y L B-.5$

CALL SETCH(XLB, YLB, $1,0,0,0)$

WRITE OUTPUT TAPE $100,46.51 G M A$

CALL SETCH(110, 4.,0,0,0,0)

$\$ \$ C N M$

WRITE OUTPUT TAPE 100,24, IFITLAB(JFITY), IFIT

140 CALL SETCH(24, . 1,0,0,0,0)

WRITE OUTPUT TAPE IOO, IO,LU,LA, (TITLE ( $), J=1, L B)$, BLANK, T I, T2

IF (IBAND) $280,2 B 0$,

DO $5250 \mathrm{~J}=1,500,5$

CALL EDEV(XP(J),SY,!)

$A A=Y P[J)+S Y$

CALL POINT (XPIJ),AA,O)

$A A=Y P(J)-S Y$

CALL FOINT(XPIJ), AA,O)

250 CONTINUE

280 IF (IWT) 300,300 ,

IF (IWT) 300,300 ,

DO $290 J=1, L X Y$

YLB $=1 . /$ WT (J)

CALL SETLCH(X(N),AA, I, 0,2,0)

CALL CRTBCDIIH-)

CALL SETLCH(X(J),BB, 1,D.2,0)

CALL CRTBCD $(1 \mathrm{H}-)$

290 CALL LINE(X(J), AA, X(J),BB)

300 CONTINUE

C

C... END OF MAIN LOOP - RETURN

$\mathrm{C}$

c.

BB8 CALL EXIT

320 WRI TE OUTPUT TAPE 3,47

GO TO 1

330 WRITE OUTPUT TAPE 3.49. IF!T

PRINT 49, IFIT

CALL DUMP

777 WRITE OUTPUT TAPE 3,707

PRINT 707

GO TO $B 88$

$c$

I0 FORMAT $\because \cdot A * 1$

20 FORMAT (IHI. *A*, III)

24 FORMAT (A $0.4 \mathrm{H} F(T, 13)$

32 FORMAT (28X, 1 2HCOEFF ICIENTS, $18 \mathrm{X}, 17$ HESTIMATED STD UEV $/ 1)$

34 FORMAT $\{10 X, 2 H C(, 12,1 \mathrm{H}), 10 X, E 18,10,14 \times, E ! 18,10)$

36 FORMA T //13X.2OHINDEPENDENT VARIABLE. 2 IX, 1BHDEPENDENT VARIABLE, $19 \mathrm{X}$

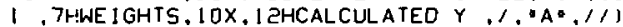

38 TORMAT (IIX,E18.10,22X,E18,10.11X,2E20,10)

40 FORMAT //2IH EST STD DEV IN FIT = EIB.10, BX,ISHRAW RMS ERROR = . 1 E18.10, 8X,13HDETERMINANT $=E(8.10 \%)$

45 FORMAT $(2 H C(, 12,4 \mathrm{H})=. \mathrm{E} 17.10)$

46 FORMAT ( 8 HSIGMA $=, E 17.10$ )

47 FORMAT // 77H LINEARIZED EXPONENTIAL FIT ATTEMPTED WITH NEGATIVE O 
IR ZERO VALUES IN ARRAY

49 FORMAT $/ / /$ 2QH -MAFIT- INPUT ERROR IFIT $=13,40 H$ MUST BE GREATER T IHAN O AND LESS THAN 11,

707 FORMAT//39H PROBLEM TERMINATED BY SENSE SWITCH 1 , ENC 


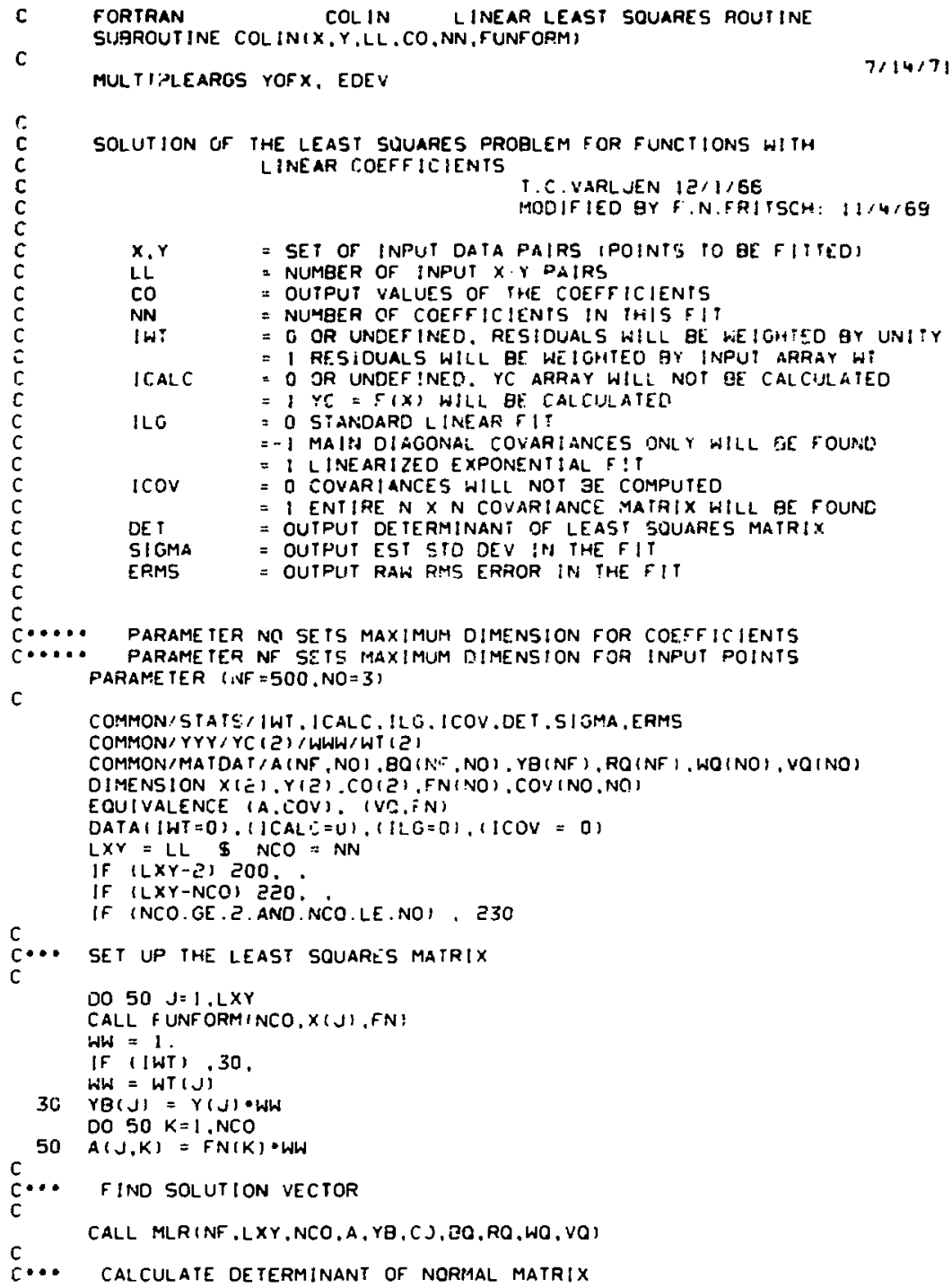




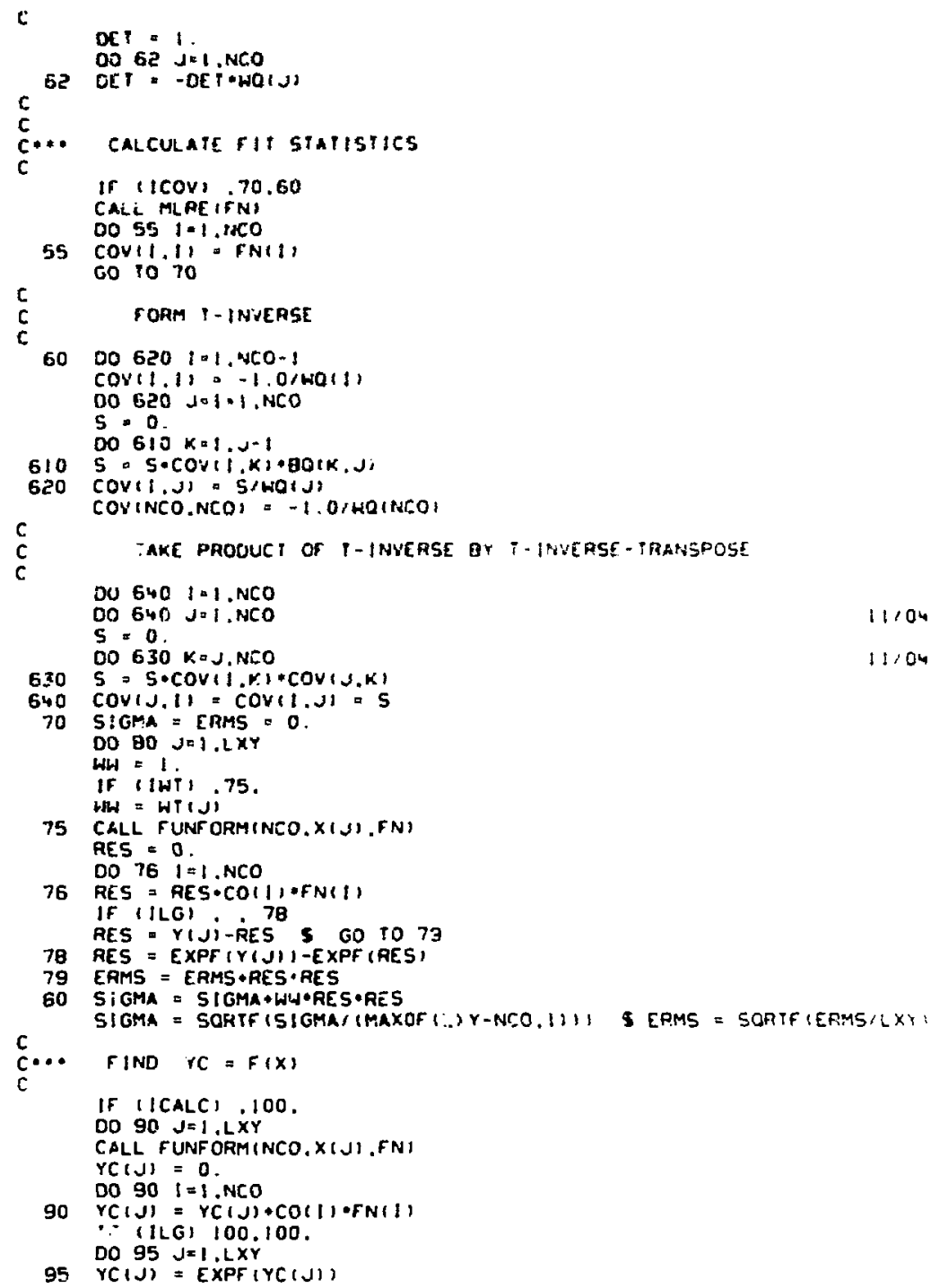




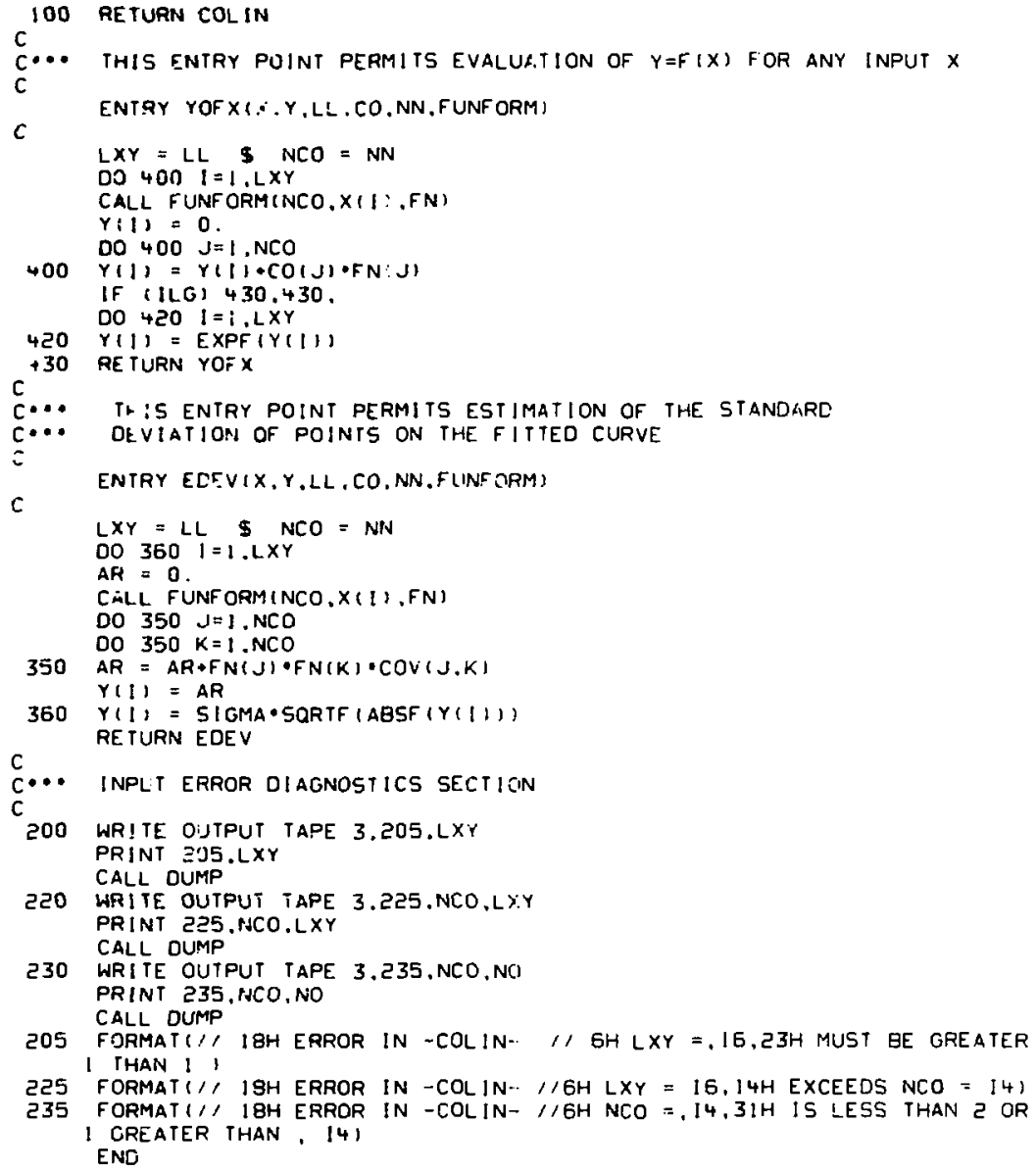




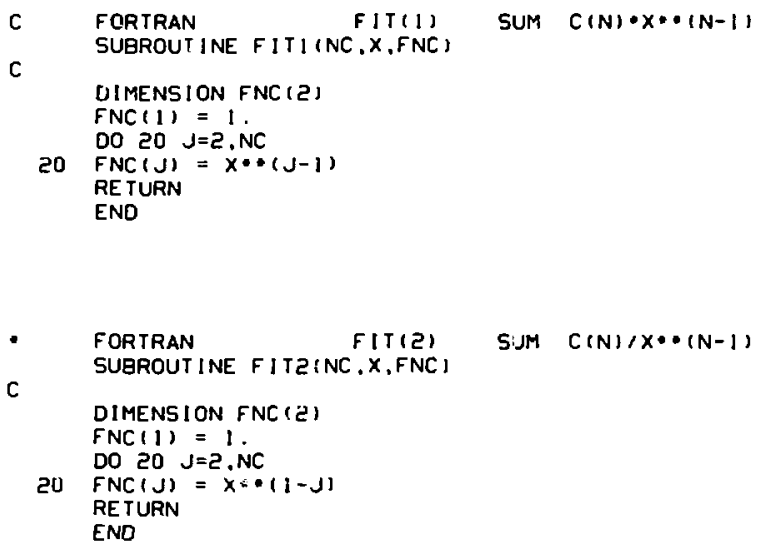

C

DIMENSION FNC (2)

$F N C(1)=1$.

DO $50 \mathrm{f}=5 . \mathrm{NC}$

5U $F N C(J)=x *(1-\lambda)$

RE TURN

END

S:JM $C(N) / X *(N-1)$

C

\section{FORTRAN}

F I T (3)

SUBROUTINE FIT3(NC, $X, F N C)$

DIMENSION FNC(2)

$F N C(1)=1.0$ \$ $151 G N=1$ \$ $K=0$

DO $50 \mathrm{~T}=5 . \mathrm{NC}$

IF (ISIGN) 10,10 .

$\mathrm{K}=\mathrm{K}+\mathrm{1}$

I0 FNCIJ) $=x+(|S| G N * K)$

20 ISIGN $=-$ ISIGN

RE TURN

END

\footnotetext{
FURTRAN

C

DIMENSION FNC ( 2$)$

DO $20 \quad J=1$. NC

$\supseteq 0 \quad F N C(J)=\operatorname{EXPF}(X \cdot J)$

RETURN

END
}

SUBROUT INE FIT $4(N C, X, F N C)$

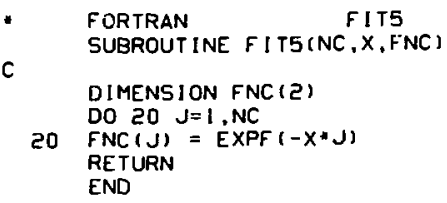

DIMENSION FNC (2)

DO $20 \quad J=1$, NC

$50 \operatorname{FNC}(J)=\operatorname{EXPF}(-X * J)$

RETURN

END

C

P(IL YNOMIAL $1+1-$ INTEGRAL POWERS ) 


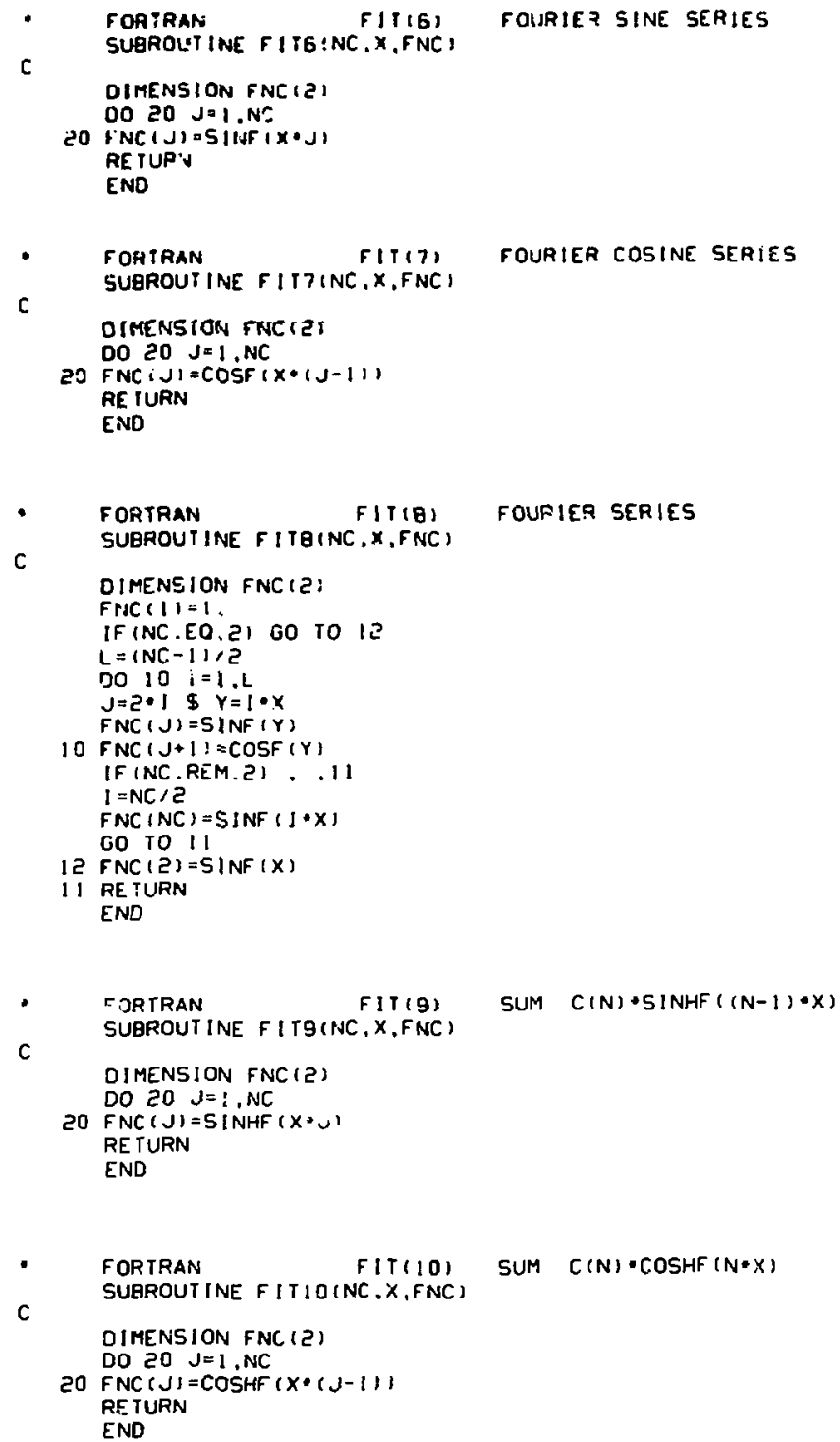

IMM/bl/la 